\title{
Study of the Optical, Electrical, Structural and Morphological Properties of Electrodeposited Lead Manganese Sulphide (PbMnS) Thin Film Semiconductors for Possible Device Applications
}

\author{
Nwori A. N. ${ }^{1 *}$, Ezenwaka L. N. ${ }^{1}$, Otti E. I. ${ }^{1}$, Okereke N. A. ${ }^{1}$, Okoli N. L. ${ }^{1,2}$ \\ ${ }^{1}$ Department of Industrial Physics, Faculty of Physical Science, Chukwuemeka Odumegwu Ojukwu University \\ Anambra State, Nigeria \\ ${ }^{2}$ Department of Physics and Electronics, Legacy University Okija, Anambra State, Nigeria \\ * Corresponding author email: austine2010forreal@yahoo.com
}

Received: 15 May 2021 / Revised: 15 September 2021 / Accepted: 07 November 2021 / Published: 04 December 2021

\begin{abstract}
Semiconductor thin films of lead manganese sulphide (PbMnS) have been successfully deposited on florinated tin oxide (FTO) conductive glass substrate using an electrodeposition method. Lead acetate $\left(\mathrm{Pb}\left(\mathrm{CH}_{3} \mathrm{COO}\right)_{2}\right)$, manganese sulphate $\left(\mathrm{MnSO}_{4} \cdot \mathrm{H}_{2} \mathrm{O}\right)$ and thiourea $\left(\mathrm{CH}_{4} \mathrm{~N}_{2} \mathrm{~S}\right)$ were the precursor used for lead $\left(\mathrm{Pb}^{2+}\right)$, manganese $\left(\mathrm{Mn}^{2+}\right)$ and sulphur $\left(\mathrm{S}^{2-}\right)$ sources respectively. The concentration of manganese $\left(\mathrm{Mn}^{2+}\right)$ was varied while keeping the concentrations of $\mathrm{Pb}^{2+}$ and $\mathrm{S}^{2-}$ constant at $0.2 \mathrm{M}$ and $0.1 \mathrm{M}$ respectively. The deposited films were annealed at temperature of $250{ }^{\circ} \mathrm{C}$ and subjected for optical, electrical, structural and morphological characterizations. The results of the characterizations showed that the deposited thin films of $\mathrm{PbMnS}$ have high absorbance, high absorption coefficient throughout VIS and NIR regions. The band gap energy of the films is tuned to the order of $1.9 \mathrm{eV}$ to $2.0 \mathrm{eV}$ and tends to constant as concentration of $\mathrm{Mn}^{2+}$ increased. The electrical properties (electrical resistivity and conductivity) of the films are dependent on the concentration of $\mathrm{Mn}^{2+}$ and film thickness. The range of values of the electrical properties is found to be within the range of values for semiconductor materials. The XRD analysis revealed that the deposited thin films of PbMnS is crystalline but the crystallinity declined with increase in concentration of $\mathrm{Mn}^{2+}$. The SEM morphology showed that the surfaces of the films are highly homogeneous in nature and particle sizes are uniform on the substrate with the majority of the particles been spherical in shape. These observed properties exhibited by the deposited thin films of $\mathrm{PbMnS}$ make the films good materials for many optoelectronic and electronic applications such as solar cell, light emitting diode (LED), photodetector etc.
\end{abstract}

Keywords: Electrodeposition, Optoelectronics, Bandgap.

\section{Introduction}

Devices made of semiconductor thin films have no doubt contributed immensely to the level of technology today and have demonstrated quite copious applications in various fields of science and technology. Few of these applications are solar cells, photoconductors, infrared detectors, waveguide coatings, temperature control of satellites, photo thermal solar coatings, magnetic films, superconducting films, anticorrosive films, anti-reflection coating, interference filters, polarizers, narrow band filters, microelectronics devices, diamond films, reduction of fabrication through coating or surface modification, high temperature wear resistance films, light sources (light emitting diodes -LED and light amplification by stimulated emission of radiation-LASER), "[1]-[7]". The performance of any semiconductor alloy for these applications is attributed to the electronic properties of the constituent elements of the material. The choice of the constituent elements of semiconductor thin film alloys can give rise to splits of materials with different performances for many applications. The basic electronic properties of elements are charge and spin properties of electrons. The charge property of electrons in semiconductor materials is basically produced 
Study of the Optical, Electrical, Structural and Morphological Properties of Electrodeposited Lead Manganese Sulphide ...........

if the materials are composed of non-magnetic materials. In the other hand, the spin property of electrons is produced by magnetic elements that constitute the materials. Lead manganese sulphide $(\mathrm{PbMnS})$ thin film semiconductor alloy is one of the semiconductor materials that is identified to constitute both magnetic and non-magnetic elements in its constituent. Ordinarily, lead sulphide (PbS) thin film is a very important binary IV-VI semiconductor material with a narrow band gap energy of $0.41 \mathrm{eV}$ and relatively large excitation Bohr radius of $18 \mathrm{~nm}$, "[8]". These properties result in strong quantum confinement of electrons and holes present in the crystal lattice of the material. The band gap energy of PbS thin films can be controlled simply by modifying particle size and shape. Quantum confinement in PbS thin films possessing significantly; broader band gaps gives rise to many interesting structural, optical and electrical properties much different from their bulk counterparts. These behaviors make it good material for light absorbers in solar cells, transistors, infrared detectors, biosensors devices, lasers, light emitting diode (LED) devices, telecommunications, optical switches, optical amplification as well as gas-sensing agents in the solid-state sensors, "[9], [10]". Incorporation of anti-ferromagnetic element-manganese into PbS crystal, grouped it into the new split of material called diluted magnetic semiconductor (DMS) thin films which have been identified as materials that have high performance potentials for many applications regarding the magnetic behaviors of their constituent elements "[11], [12]". This new form of material (PbMnS) can be prepared by varieties of methods. Mahashabde et al., "[13]" used chemical bath method to deposit ternary thin films of $\mathrm{Pb}_{\mathrm{x}} \mathrm{Mn}_{1-\mathrm{x}} \mathrm{S}$ having composition $(\mathrm{x}=0.5)$ on Pyrex glass substrate at $45^{\circ} \mathrm{C}$ for $35-50$ minutes using manganese acetate, lead acetate and thiourea as starting materials and studied their structural properties. Chidambara et al., "[14]" used successive ionic layer adsorption and reaction method (SILAR) to grow manganese doped lead sulphide thin films on glass substrate and reported that stress exists for all the manganese doped PbS thin films deposited. Chidambara et al., [15] investigated the structural, optical and magnetic properties of $\mathrm{Mn}$ doped $\mathrm{PbS}$ thin films fabricated using SILAR method. They reported that the films have preferential orientation along (2 00 ) plane, optical bandgap energy varied from $2.8 \mathrm{eV}$ to $3.1 \mathrm{eV}$ as manganese content increases and behave as a soft magnetic material according to the vibrating sample magnetometer (VSM) studies. The effect of bandgap broadening of Mn doped PbS quantum dots (QDs) reproduced using pulse laser deposition (PLD) synthesis have been reported by Yost et al., "[16]" and they concluded that the variation in bandgap broadening is as a result of the Mn dopant locations, inside the surface of the QDs. They claim the results provide clear information on how the transition metal element doping locations in semiconducting QDs influence the electronic density of state (DOS) of the host QDs. The incorporation of other magnetic materials order than manganese into the $\mathrm{PbS}$ structure have demonstrated significantly enhanced performance of their device applications as reported by "[17]". In this work, we used electrodeposition method to deposit ternary chalcogenide thin film semiconductor alloys of $\mathrm{PbMnS}$ on florine doped tin oxide (FTO) conductive glass substrate to study their optical, electrical and structural properties for possible applications.

\section{Materials and Method}

The semiconductor thin films of $\mathrm{PbMnS}$ were deposited using an electrodeposition technique at room temperature using Potentiostat (model Zhaoxin: RXN-3010D). Lead acetate $\left(\mathrm{Pb}\left(\mathrm{CH}_{3} \mathrm{COO}\right)_{2}\right)$, Manganese sulphate $\left(\mathrm{MnSO}_{4} \cdot \mathrm{H}_{2} \mathrm{O}\right)$ and Thiourea $\left(\mathrm{CH}_{4} \mathrm{~N}_{2} \mathrm{~S}\right)$ were the main starting materials used to source for lead $(\mathrm{Pb})$ ions $\left(\mathrm{Pb}^{2+}\right)$, manganese $(\mathrm{Mn})$ ions $\left(\mathrm{Mn}^{2+}\right)$, Sulphur $(\mathrm{S})$ ions $\left(\mathrm{S}^{2-}\right)$. Sodium tri-sulphate $\left(\mathrm{Na}_{2} \mathrm{SO}_{3}\right)$, Ethylenediaminetetraacetic acid (EDTA) $\left(\mathrm{C}_{10} \mathrm{H}_{16} \mathrm{~N}_{2} \mathrm{O}_{8}\right)$ and Distilled water were the secondary materials used as supporting electrolyte, complexing agent and reaction medium respectively. Floourine-doped tin oxide (FTO) conductive glass substrate was used as working electrode and washed with acetone in an ultrasonic machine for one hour and dried in an electric oven. Two digital multimeter (DT890C7 and mastech: MY60) were used for measuring current and voltage respectively. Three electrodes configuration systems of electrodeposition technique were employed to deposit the thin films of $\mathrm{PbMnS}$ on the FTO glass substrate. 


\subsection{Preparation of PbMnS Thin Films}

To prepare the thin films of $\mathrm{PbMnS}, 10 \mathrm{ml}$ of $0.2 \mathrm{M}$ Lead acetate $\left(\mathrm{Pb}\left(\mathrm{CH}_{3} \mathrm{COO}\right)_{2}\right), 10 \mathrm{ml}$ of $0.1 \mathrm{M} \mathrm{CH}_{4} \mathrm{~N}_{2} \mathrm{~S}$, $10 \mathrm{ml}$ of $0.1 \mathrm{M} \mathrm{Na}_{2} \mathrm{~S}_{3} \mathrm{O}_{4}$ and $5 \mathrm{ml}$ of $0.025 \mathrm{M}$ EDTA as a complexing agent with $0.05 \mathrm{M}$ concentrations of $\mathrm{MnSO}_{4}$ were reacted in an electrochemical cell. The deposition of the films was initiated on the surface of the working electrode at constant potential of $1.8 \mathrm{~V}$ by passage of current through the solution of the complexes and allowed to stay for 90 seconds. The process was repeated by varying the concentrations of $\mathrm{Mn}^{2+}$ source in the order of $0.05,0.1,0.15$ and $0.25 \mathrm{M}$ and the deposited films were removed from the cell and washed with distilled water and annealed in an oven at temperature of $250{ }^{\circ} \mathrm{C}$ for 5 minutes. These processes are summarized in the Table 1.

Table 1: Preparation of PbMnS Thin Films at Varying Concentration of $\mathrm{Mn}^{2+}$

\begin{tabular}{|c|c|c|c|c|c|c|c|c|c|c|c|c|}
\hline \multirow[t]{2}{*}{ Bath Name } & \multicolumn{2}{|c|}{ Pb-acetate } & \multicolumn{2}{|c|}{$\mathrm{MnSO}_{4} \cdot \mathrm{H}_{2} \mathrm{O}$} & \multicolumn{2}{|c|}{$\mathrm{CH}_{4} \mathrm{~N}_{2} \mathrm{~S}$} & \multicolumn{2}{|c|}{ EDTA } & \multicolumn{2}{|c|}{$\mathrm{Na}_{2} \mathrm{SO}_{4}$} & \multirow{2}{*}{$\begin{array}{l}\text { Voltage } \\
\text { (Volts) }\end{array}$} & \multirow{2}{*}{$\begin{array}{l}\text { Time } \\
\text { (secs) }\end{array}$} \\
\hline & $\begin{array}{l}\text { Conc } \\
(\mathrm{mol})\end{array}$ & $\begin{array}{l}\text { Vol } \\
(\mathrm{ml})\end{array}$ & $\begin{array}{l}\text { Conc } \\
(\mathrm{mol})\end{array}$ & $\begin{array}{l}\text { Vol } \\
\text { (ml) }\end{array}$ & $\begin{array}{l}\text { Conc } \\
\text { (mol) }\end{array}$ & $\begin{array}{l}\text { Vol } \\
\text { (ml) }\end{array}$ & $\begin{array}{l}\text { Conc } \\
\text { (mol) }\end{array}$ & $\begin{array}{l}\text { Vol } \\
\text { (ml) }\end{array}$ & $\begin{array}{l}\text { Conc } \\
\text { (mol) }\end{array}$ & $\begin{array}{l}\text { Vol } \\
(\mathrm{ml})\end{array}$ & & \\
\hline $0.05 \mathrm{M} \mathrm{Mn}^{2+}$ & 0.2 & 10 & 0.05 & 10 & 0.1 & 10 & 0.025 & 5.0 & 0.05 & 10 & 1.80 & 90.00 \\
\hline $0.10 \mathrm{M} \mathrm{Mn}^{2+}$ & 0.2 & 10 & 0.10 & 10 & 0.1 & 10 & 0.025 & 5.0 & 0.05 & 10 & 1.80 & 90.00 \\
\hline $0.15 \mathrm{M} \mathrm{Mn}^{2+}$ & 0.2 & 10 & 0.15 & 10 & 0.1 & 10 & 0.025 & 5.0 & 0.05 & 10 & 1.80 & 90.00 \\
\hline $0.20 \mathrm{M} \mathrm{Mn}^{2+}$ & 0.2 & 10 & 0.20 & 10 & 0.1 & 10 & 0.025 & 5.0 & 0.05 & 10 & 1.80 & 90.00 \\
\hline $0.25 \mathrm{M} \mathrm{Mn}^{2+}$ & 0.2 & 10 & 0.25 & 10 & 0.1 & 10 & 0.025 & 5.0 & 0.05 & 10 & 1.80 & 90.00 \\
\hline
\end{tabular}

\subsection{Characterizations of the Deposited Thin Films}

To determine the optical, electrical and structural properties of the deposited thin films of PbMnS alloys, the films were subjected for optical analysis using UV-VIS Spectrophotometer of model U756S-19-018 to measure the absorbance of the films. The optical absorbance (A) was measured directly from the spectrophotometer machine and analyzed in the wavelength range of 200-1100 nm, while other optical properties were calculated using appropriate relations. The electrical properties were determine using four probe configurations connected to Keithley source meter of model 2400 LV to measure the resistivity of the films. EMPYREAN Diffractometer and MIRA 3 TESCAN scanning electron microscopy were used to measure the crystalline structure and morphology of the films respectively.

\section{Results and Discussions.}

\subsection{Optical Properties of the as Deposited (PbMnS) Thin Films}

The plot of absorbance as a function of wavelength for the deposited thin films of $\mathrm{PbMnS}$ is presented in figure 1.

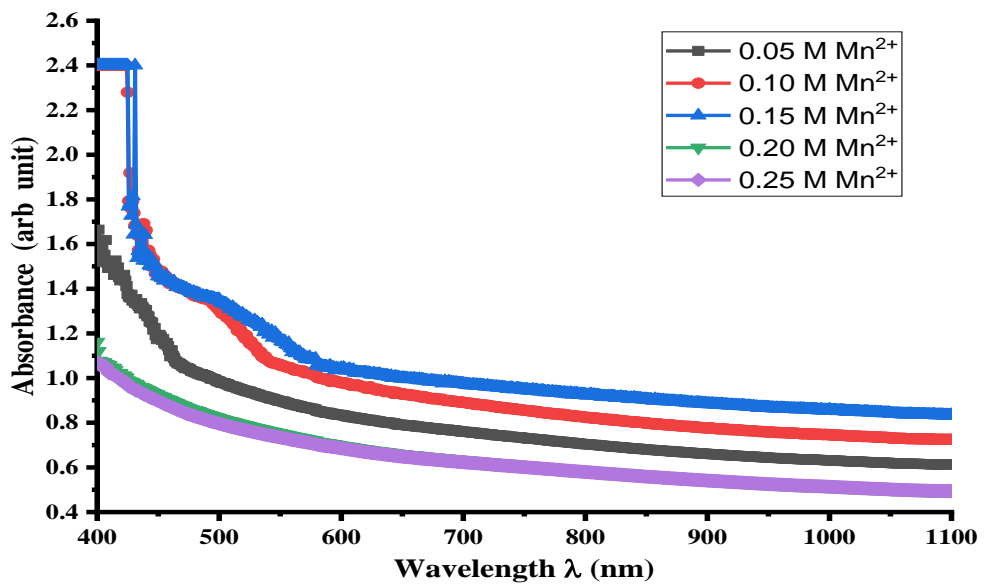

Figure 1: Graph of Absorbance against wavelength for PbMnS thin films 
Study of the Optical, Electrical, Structural and Morphological Properties of Electrodeposited Lead Manganese Sulphide ...........

The figure showed that the absorbance of the films is high (in the order of 0.6-2.4) but decreases as wavelength increased. The absorbance initially increased as concentration of $\mathrm{Mn}^{2+}$ increased from $0.05 \mathrm{M}$ to $0.15 \mathrm{M}$ but decreased to lower values with further increase in $\mathrm{Mn}^{2+}$ concentration from $0.20 \mathrm{M}$ to 0.25 $\mathrm{M}$ throughout the visible (VIS) and near infra-red (NIR) regions. High absorbance films of this nature have been reported by "[18]" and can be used for window coatings in the high temperature regions of the world such as sub-saharan Africa like Nigeria. This is because the harmful ultraviolet rays can be absorb by the device coated with the films thereby keeping the inside houses cool and subsequently replace the conventional air conditioning that are of high demand in the regions at cheap price.

Transmittance $(\mathrm{T})$ of the deposited thin films of PbMnS was calculated using the relation as given by [19]

$T=10^{-A}$

where $\mathrm{A}$ is the measured absorbance of the films.

The plot of the percentage transmittance of the films against wavelength is presented in Figure 2.

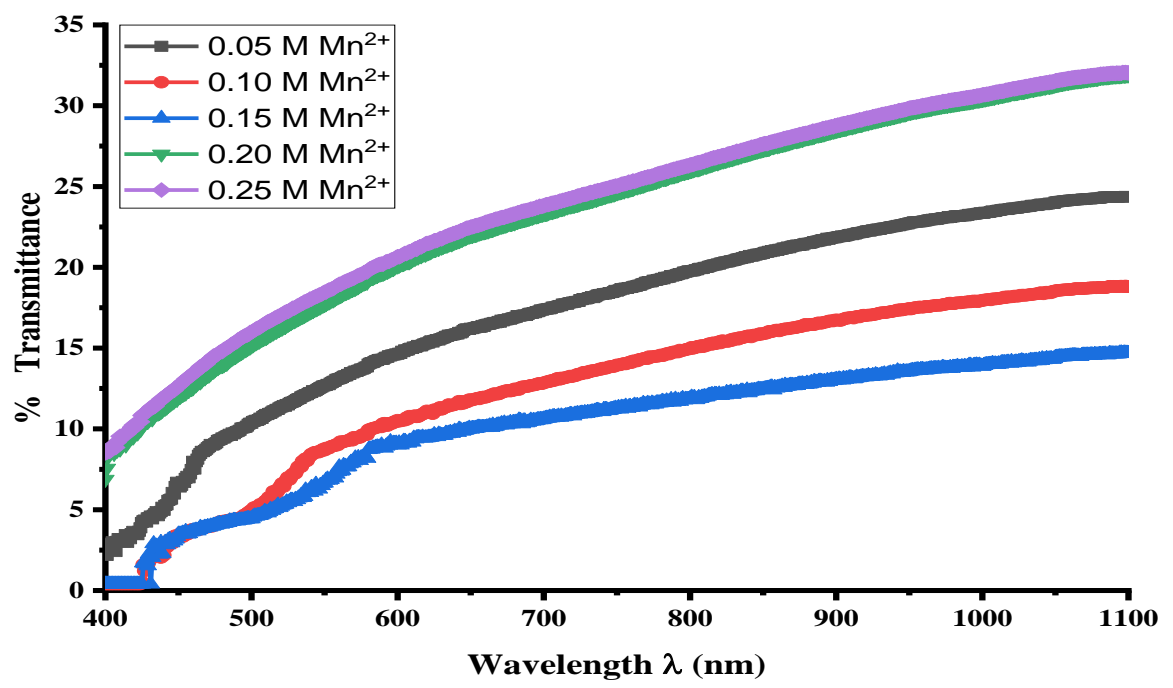

Figure 2: Graph of \% Transmittance against wavelength for PbMnS thin films

The figure indicated that the transmittance of the films is low (in the range of $0-35 \%$ ). However, the transmittance increases with an increase in wavelength thereby suggesting higher transmittance values in the near infra-red (NIR) region. The low transmittance coupled with high absorbance of the films position them for photovoltaic solar cell application for solar energy haenessing. Similar results from manganese $(\mathrm{Mn})$, chromium ( $\mathrm{Cr}$ ) and barium $(\mathrm{Ba})$ doped $\mathrm{PbS}$ thin films deposited by chemical bath deposition and successive ionic layer adsorption reaction (SILAR) method respectively have been "reported by [20] - [22]".

Figure 3 is the graph showing the plot of absorption coefficient as a function of wavelength for the deposited thin films. The absorption coefficient $(\alpha)$ was calculated using the formula "as given by [23, 24]".

$\alpha=\frac{1}{t_{f}}\left(\log T^{-1}\right)$

where $t_{f}$ is the film thickness and $T$ is the transmittance as calculated from equation (1). The figure showed that the films have high absorption coefficient which is in the order of $10^{5} \mathrm{~cm}^{-1}$. The absorption coefficient increased as concentration of $\mathrm{Mn}^{2+}$ increased up to the concentration of $0.15 \mathrm{M}$ and thereafter decreased to lower values of $1.33 \times 10^{4} \mathrm{~cm}^{-1}$ as concentration of $\mathrm{Mn}^{2+}$ increased passed $0.15 \mathrm{M}$ throughout the VIS 
Nwori et al., J. Mod. Mater.; Vol. 8, Issue 1, pp: 40-51, 2021

and NIR regions. The high absorption coefficient exhibited by the films position them for solar cell application and other optoelectronic applications such as sensor devices.

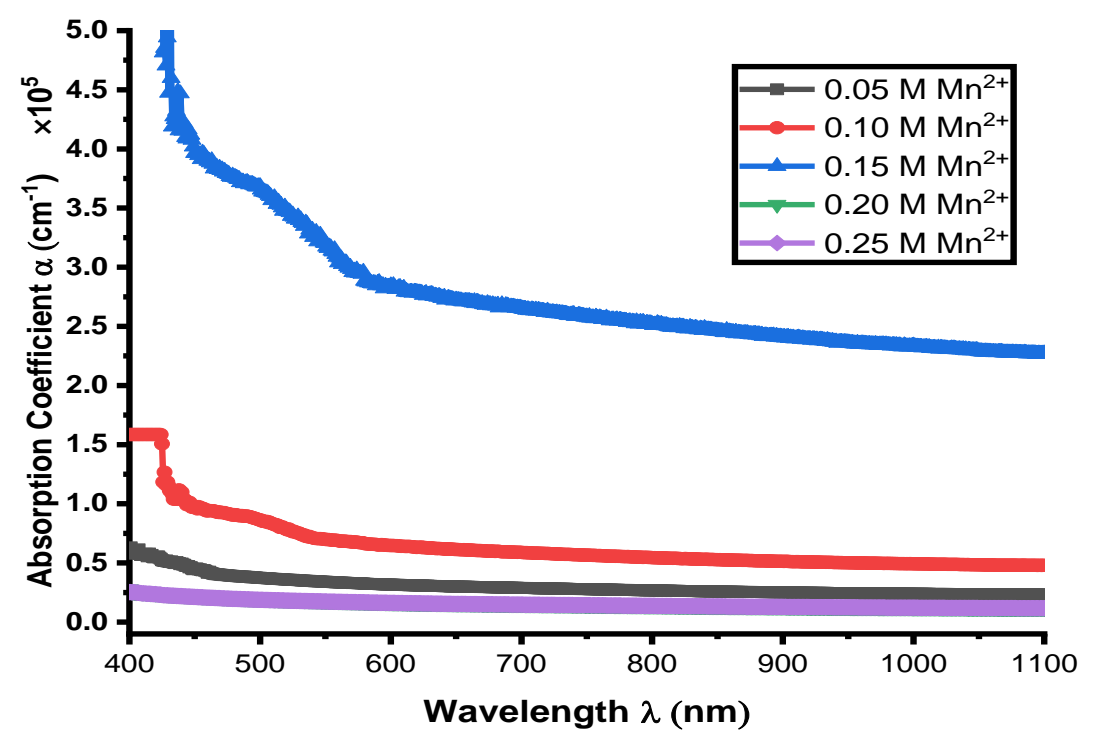

Figure 3: Graph of Absorption coefficient against wavelength for PbMnS thin films

The extinction coefficient of the deposited thin films which determines the rate at which light lost in the films was calculated using the relation "given by [25], [26]".

$k=\frac{\alpha \lambda}{4 \pi}$

where $\lambda$ is wavelength of light and $\alpha$ is the absorption coefficient of the films.

The plot of the extinction coefficient against wavelength is presented in figure 4 . The figure indicates that the extinction coefficient of the films is low and initially increased as concentration of $\mathrm{Mn}^{2+}$ increased up to $0.15 \mathrm{M}$ but started to decrease as the concentration of $\mathrm{Mn}^{2+}$ increased further throughout the VIS and NIR regions of electromagnetic spectrum. The low value of the extinction coefficient of the films make the films good material for photodetector application as the rate at which light energy is lost in the device made of the films for applications will be very low.

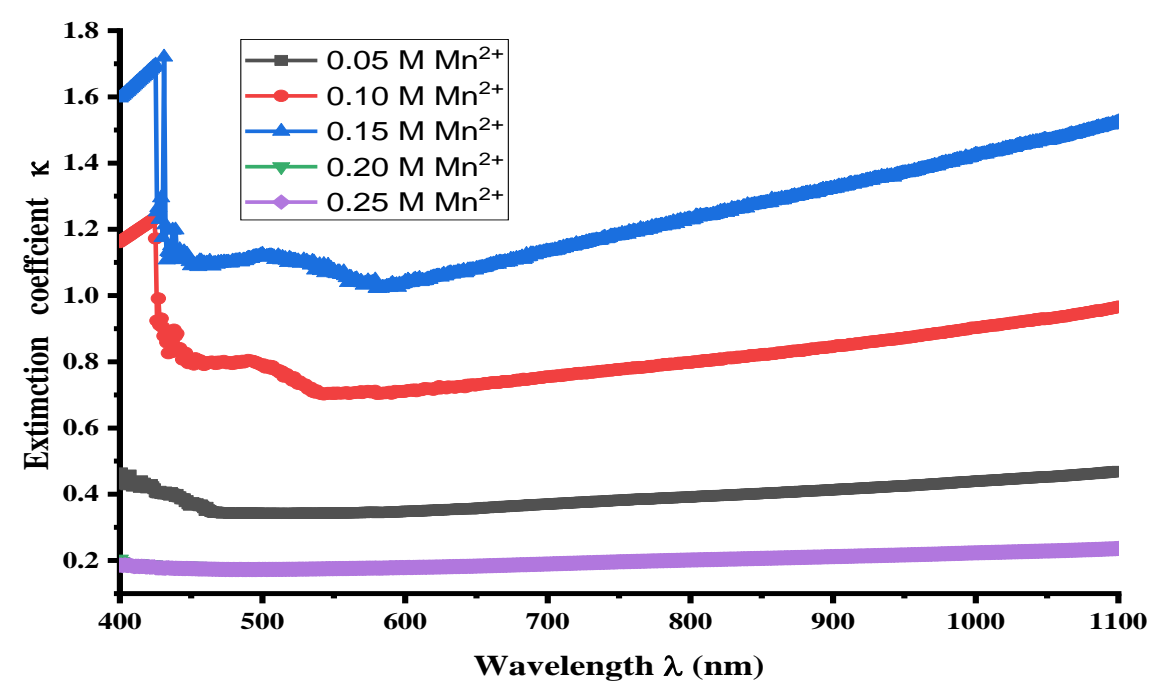

Figure 4: Graph of Extinction coefficient against wavelength for PbMnS thin films 
Study of the Optical, Electrical, Structural and Morphological Properties of Electrodeposited Lead Manganese Sulphide ...........

The bandgap energy $\left(\mathrm{E}_{\mathrm{g}}\right)$ of the films was estimated from the plot of Tauc relation "as given by [27] - [29]".

$\alpha h v=A\left(h v-E_{g}\right)^{n}$

Where $\mathrm{n}$ is the transition factor which equals to $1 / 2$ for direct band electronic transition, 2 for indirect band electronic transition, $3 / 2$ for direct forbedden transition and 3 for indirect forbedden transition, $A$ is a constant called the band trailing parameter, $h$ is the plank constannt, $v$ is the frequency and $\alpha$ is the absorption coefficient. The plot of $(\alpha \mathrm{hv})^{2}$ against photon energy (hv) (figure 5) was used to determine the direct bandgap energy of the deposited thin films of $\mathrm{PbMnS}$ by extrapolating the straight line portion of the photon energy axis at $(\alpha \mathrm{hv})^{2}$ equals to zero.
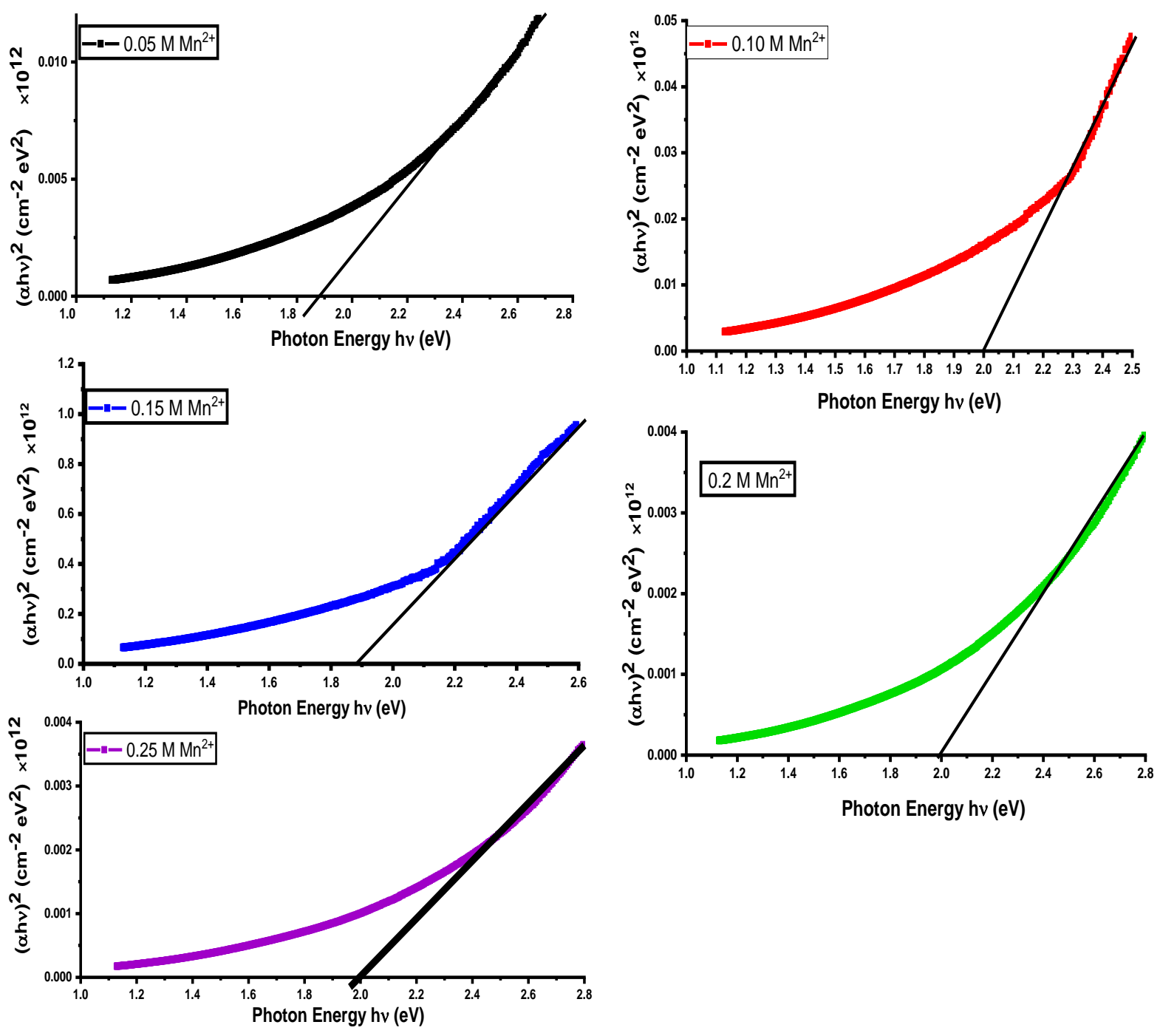

Figure 5: Graph of $(\alpha h v)^{2}$ against Photon energy for PbMnS thin films

From the figure, it is observed that the bandgap energy of all the films is $2.0 \mathrm{eV}$ except for the films deposited with the $0.05 \mathrm{M}$ and $0.15 \mathrm{M}$ concentrations of $\mathrm{Mn}^{2+}$ whose values decreased to $1.9 \mathrm{eV}$ each. Similar result of bandgap tunning to the values in this range in addition to high absorbance values for the thin films of PbS doped with rare earth element (terbium - Tb) have also been "reported by [30]". This tunned range of bandgap values for the deposited thin films of $\mathrm{PbMnS}$ is within the solar spectrum (UVVIS regions) and are thus ideal materials for solar cell applications for solar energy harnessing and development. 


\subsection{Electrical Properties of the as deposited thin films of PbMnS}

The electrical resistivity $(\rho)$ and conductivity $(\sigma)$ of the deposited films were obtained from the relation "as given by [31], [32]”.

$\rho=4.53236 t_{f} \frac{V}{I}$

$\sigma=1 / \rho$

Where $t_{f}$ is the film thickness, $V$ is the voltage drop measured across the inner probes and $I$ is the current applied at the outer probes. The plot of electrical properties (electrical resistivity and conductivity) of the films against concentration of $\mathrm{Mn}^{2+}$ is shown in figure 6 .

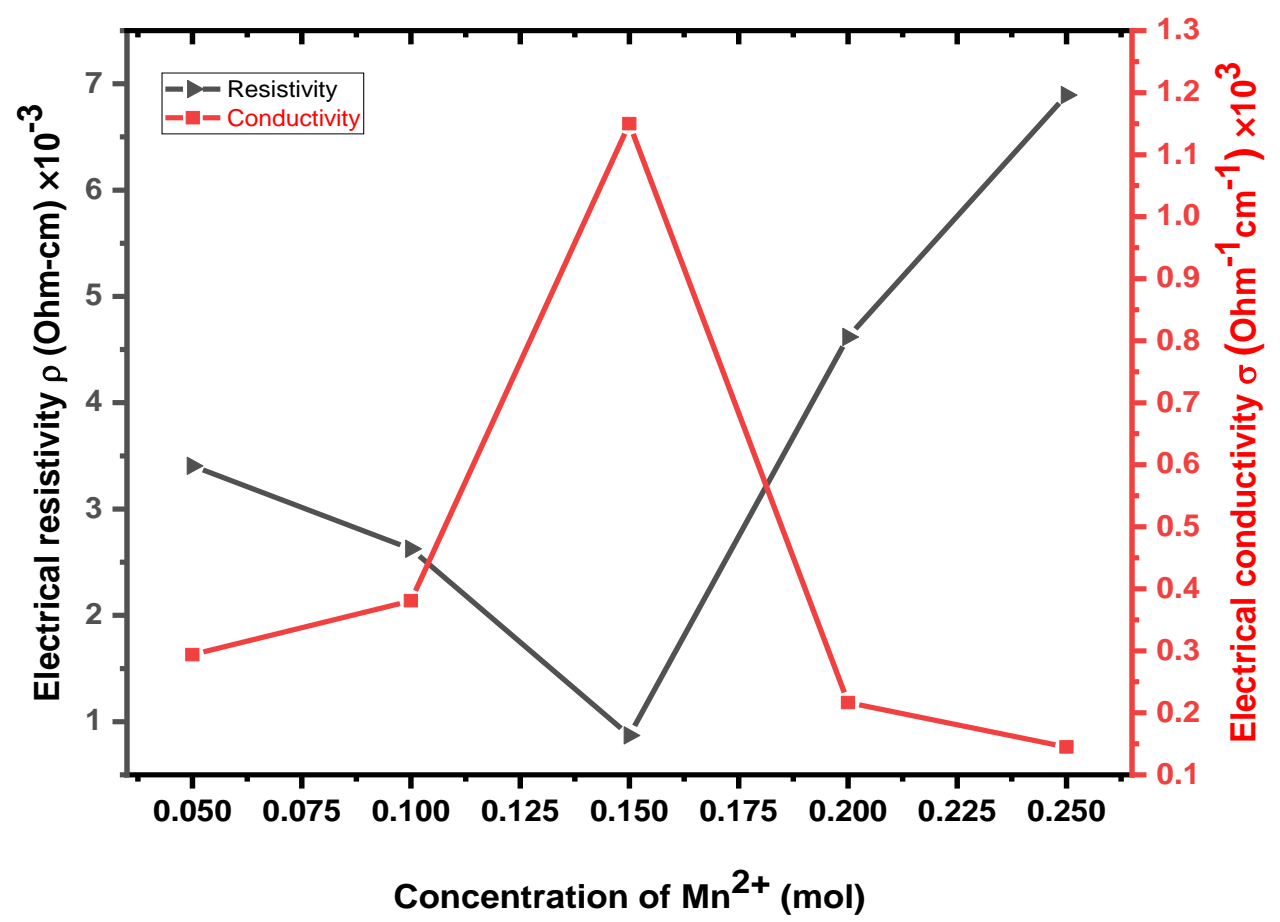

Figure 6: Plot of Electrical properties against concentration of $\mathrm{Mn}^{2+}$ for the PbMnS thin films

The figure showed that the resistivity of the films decreased to a minimum value of $1.0 \times 10^{-3} \mathrm{ohm}-\mathrm{cm}$ at the film deposited with $\mathrm{Mn}^{2+}$ concentration of $0.15 \mathrm{M}$ then increased to maximum value of $7.0 \times 10^{-3} \mathrm{ohm}-$ $\mathrm{cm}$ as concentration of $\mathrm{Mn}^{2+}$ increased further to $0.25 \mathrm{M}$. The electrical conductivity of the films increase to maximum value of $1.2 \times 10^{3} \mathrm{ohm}^{-1} \mathrm{~cm}^{-1}$ at the film deposited with concentration of $0.15 \mathrm{M}$ and thereafter decreased as concentration of $\mathrm{Mn}^{2+}$ increased. From the figure, it can be seen that the values of the electrical resistivity and conductivity of the films are within the range of values for semiconductor materials. The plot of electrical resistivity and conductivity of the films against film thickness presented in figure 7 showed that the electrical resistivity of the films is minimum at film thickness of $262.5 \mathrm{~nm}$ and then increased to higher value of $7.0 \times 10^{-3} \mathrm{ohm}-\mathrm{cm}$ as film thickness increased. The electrical conductivity of the films increased to maximum value of $1.2 \times 10^{3} \mathrm{ohm}^{-1} \mathrm{~cm}^{-1}$ as film thickness increased to a value of $262.5 \mathrm{~nm}$ then decreased as thickness increased further. The range of value of the thickness of the deposited thin films of $\mathrm{PbMnS}$ is 150 to $425 \mathrm{~nm}$. The range of values of the electrical properties for the films are in the range for semiconductor materials, hence confirming the semiconducting nature of the films for device applications. 


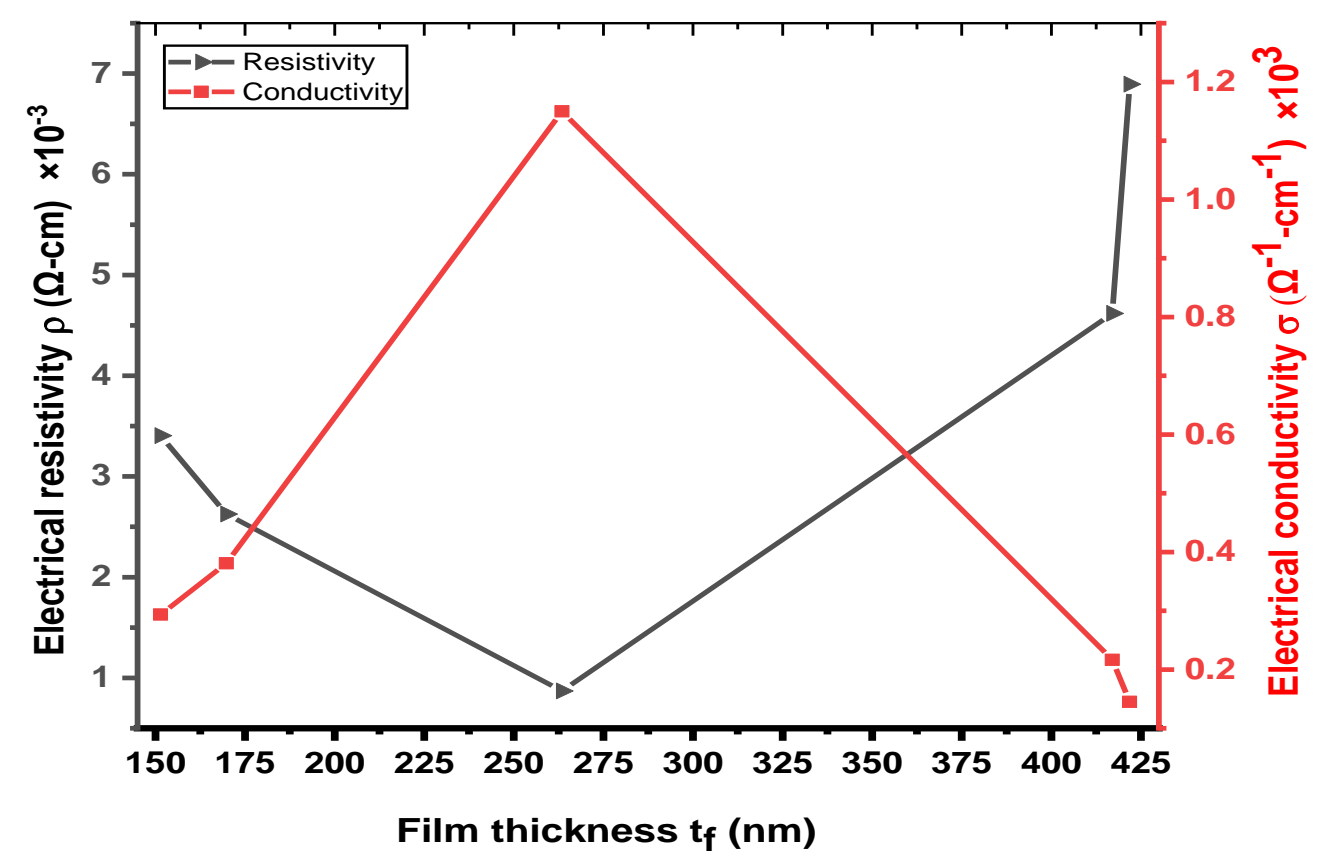

Figure 7: Plot of Electrical properties against film thickness for the PbMnS thin films

\subsection{Structural Properties of the as Deposited Thin Films of PbMnS}

The structural properties of the films were studied using X-ray diffraction (XRD) method. Figure 8 is the $\mathrm{XRD}$ pattern for the thin films of PbMnS deposited with different concentrations of $\mathrm{Mn}^{2+}(0.05 \mathrm{M}, 0.10$ $\mathrm{M}, 0.15 \mathrm{M}, 0.20 \mathrm{M}$ and $0.25 \mathrm{M})$.

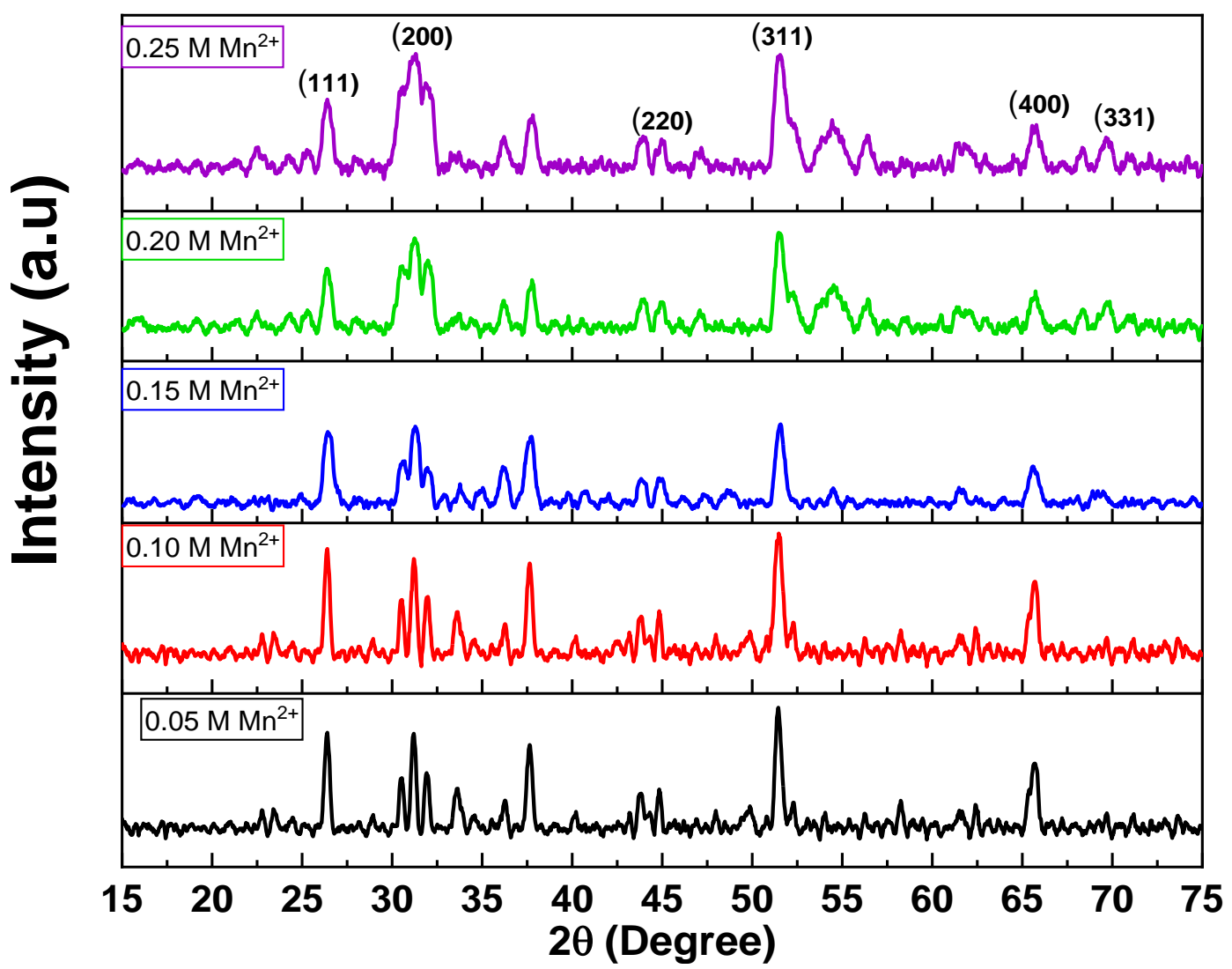

Figure 8: XRD patterns of the deposited PbMnS thin films 
From the figure, it is observed that the deposited thin films of PbMnS are crystalline. However, the crystalline nature decreases with increase in concentration of $\mathrm{Mn}^{2+}$ as the peaks of the XRD pattern became broadened at the higher concentration of $\mathrm{Mn}^{2+}$. The XRD pattern of the films showed preferential orientation at two theta angles $26.40^{\circ}, 31.30^{\circ}, 44.20^{\circ}, 51.43^{\circ}, 54.56^{\circ}, 65.71^{\circ}$ and $69.81^{\circ}$; which are indexed to the crystal planes (111), (200), (220), (311), (222), (400) and (331) respectively. The additional peaks that emerged in the XRD pattern is evidencing the presence of manganese in the crystal of the material. The films are cubic with the space group Fm-3m. These values match well with standard data (JCPDS No: 00002-1431). The average crystallite size, dislocation density and micro strain of the films calculated using the Dybe-Scherer and Williamson-Smallman relation "as given by [33] - [37]".

$D=\frac{0.9 \lambda}{\beta \operatorname{Cos} \theta}$

$\delta=\frac{1}{D^{2}}$

$\varepsilon=\frac{\beta}{4 \tan \theta}$

Where $\mathrm{k}$ is the shape factor, $\lambda$ is the $\mathrm{x}$-ray wavelength, $\boldsymbol{\beta}$ is the full weight at half maximum (FWHM) and $\theta$ is the Bragg's angle in radian are; $5.05 \mathrm{~nm}, 1442.38 \times 10^{-3}$ lines $/(\mathrm{nm})^{2}$ and $121.36 \times 10^{-3}$ respectively. The silmilar results of thin films of PbS doped with Mn with low crystallite size close to this work have been "reported by [38]".

\subsection{Morphological Properties of the as Deposited (PbMnS) Thin Films}

Figure 9 is the scanning electron microscopy (SEM) micrographs of the deposited PbMnS thin films. The figure showed that the films of PbMnS prepared with $0.05 \mathrm{M} \mathrm{Mn}^{2+}$ has uniform morphology that are of good quality and cover the entire glass substrate very well.

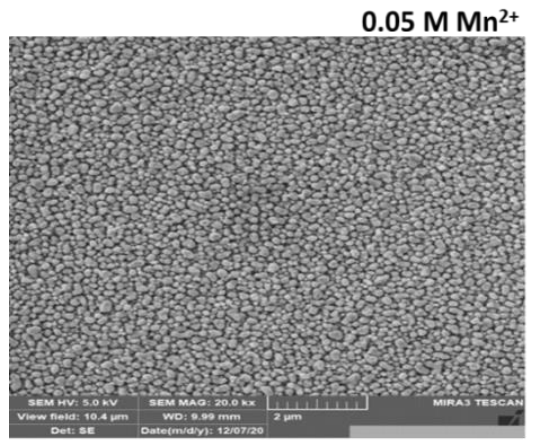

$0.20 \mathrm{M} \mathrm{Mn}^{2+}$

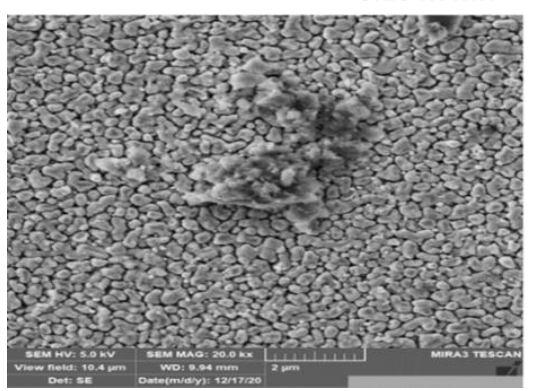

$0.10 \mathrm{M} \mathrm{Mn}^{2+}$

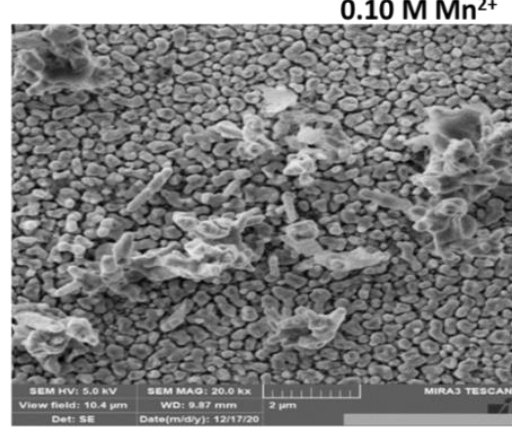

$0.25 \mathrm{M} \mathrm{Mn}^{2+}$

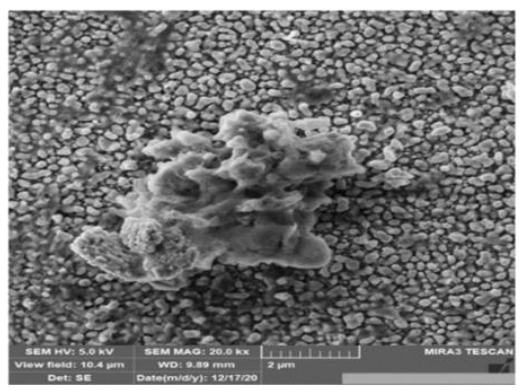

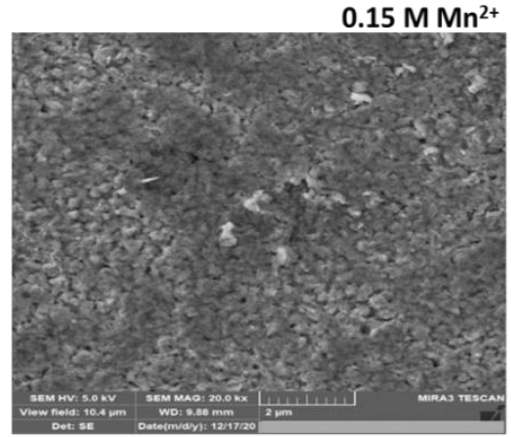

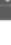

Figure 9: SEM micrographs of the deposited PbMnS thin film

The morphology composed of micro rod like particles that are irregular in shape as well as some smaller particles that are spherical in shapes and sizes. In the other hand the morphology of the films deposited with $0.10 \mathrm{M} \mathrm{Mn}^{2+}$ is also uniformly distributed but has particle sizes that are entirely irregular in shapes. 
Study of the Optical, Electrical, Structural and Morphological Properties of Electrodeposited Lead Manganese Sulphide ...........

The morphology of the films deposited with $0.15 \mathrm{M} \mathrm{Mn}^{2+}$ is uniformly distributed on the surface of substrate and composed of particles that are irregular and spherical in shapes. The film deposited with 0.20 $\mathrm{M} \mathrm{Mn}^{2+}$ is also uniformly distributed on the surface of the glass substrate. The particle sizes also consist of mixture of spherical and irregular shape but has a fibrous-like structure that is formed on top. In the other hand, the SEM micrographs of the thin film deposited with $0.25 \mathrm{M} \mathrm{Mn}^{2+}$ show that the surface of the film is highly homogeneous in nature and particle sizes are uniformly formed on the substrate. It can be seen that the majority of the particles are spherical in shape and are of good quality.

\section{Conclusion}

The analysis of the results of the characterisation of thin films of PbMnS deposited using an electrodeposition method for possible device applications has been carried out. The results showed that optical properties such as absorbance and absorption-coefficient of the films are high while the extinction coefficient is low in both the VIS and NIR regions. The percentage transmittance is low in the VIS region but increased towards the NIR region. The bandgap energy of the films was found to be in the range of 1.9 $\mathrm{eV}$ to $2.0 \mathrm{eV}$. The optical properties of the films investigated are found to be dependent on the concentration of $\mathrm{Mn}^{2+}$ as well as wavelength dependent. The films absorb high in the VIS region compare to NIR region of electromagnetic spectrum, consequently transmit is higher in the NIR. The results of the electrical characterization showed that the values of electrical properties (electrical resistivity and conductivity) of the films are within the range of values for semiconductor materials and equally dependent on the concentration of $\mathrm{Mn}^{2+}$ and film thickness. The minimum value of electrical resistivity and consequently the maximum electrical conductivity of the films were obtained when the films are deposited with the $\mathrm{Mn}^{2+}$ concentration of $0.15 \mathrm{M}$. The electrical resistivity of the films is found to increase as film thickness increased. The range of values of the electrical conductivity confirmed the semiconcting nature of the deposited thin films for semiconductor device applications. The XRD analysis revealed that the deposited thin films of $\mathrm{PbMnS}$ have cubic structure and are generally crystalline in nature but the crystallinity declined with increase in the concentration of $\mathrm{Mn}^{2+}$. The SEM morphology show that the surfaces of the films are highly homogeneous and particle sizes are uniform but the majority of the particles are spherical in shape. These properties exhibited by the deposited thin films of $\mathrm{PbMnS}$ make them good materials for many opto-electronic and electronic applications such as in solar cells, light emitting diode (LED), photodetectors etc. In view of these observed properties of the deposited thin films, it is recommended that for optimal result to be achieved the films of this nature should be deposited with concentration of $\mathrm{Mn}^{2+}$ within $0.15 \mathrm{M}$ region and film thickness should be within the range $250 \mathrm{~nm}$ to 300 $\mathrm{nm}$.

\section{Declarations}

\subsection{Limitations of the Study}

Lack of research and development grants remain the potential treat to the study.

\subsection{Acknowledgement}

The authors are pleased to appreciate and acknowledge the following individuals; Prof. Ezema, F. I., Mr. Whyte F. M., Mr. Nsude Kingsley Ugonna, and Mrs. Nsude Ebere of Nanotech Laboratory, University of Nigeria Nsukka (UNN), Nigeria and Nura Adamu Mohammed of National Geosciences Research Laboratories, Nigeria Geological Survey Agency, Kadunan State Nigeria, for making their laboratories available to carry out characterizations of their samples.

\subsection{Competing Interests}

The authors declared that there is no conflict of interest that existed in the publication of the work. 
Nwori et al., J. Mod. Mater.; Vol. 8, Issue 1, pp: 40-51, 2021

\section{How to Cite this Article:}

A. N. Nwori, N. L. Ezenwaka, I. E. . Ottih, N. A. . Okereke, and N. L. Okoli, "Study of the Optical, Electrical, Structural and Morphological Properties of Electrodeposited Lead Manganese Sulphide (PbMnS) Thin Film Semiconductors for Possible Device Applications", J. Mod. Mater., vol. 8, no. 1, pp. 40-51, Dec. 2021. https://doi.org/10.21467/jmm.8.1.40-51

\section{References}

[1] L. R. Singh, A.N. Singh, S. N. Singh and S. B. Singh, "Structural Characterization of PbS and Cd-doped PbS Nanocrystalline Thin Film Fabricated By Chemical Bath Deposition Technique” Int. J. Inn. Res. Sci. Eng. Technol. vol. 7, no 1, pp. 537-541, January 2018.

[2] M. Zendehdel, N. Y. Nia and M Yaghoubinia. Emerging Thin Film Solar Panels, Reliability and Ecological Aspects of Photovoltaic Modules, Abdülkerim Gok, IntechOpen, January 8th 2020. https://www.intechopen.com/chapters/68684

[3] S. Sinha, H. Feng, C. Chung, C. Tu, and R. H. Horng. Comparison of Properties of Thin Film AlGaInP LEDs with Composite Metal and Si Substrates. ECS J. Solid State Sci. Technol. vol 9, no 1, pp. 1-5, November 2019.

[4] R. Birney, "Current Research in Thin Film Deposition: Applications, Theory, Processing, and Characterisation," Coatings, vol. 10, no. 1228, PP. 1 - 4, December 2020.

[5] M. Hosseini, M. Javad and R. A Nawrocki, "A Review of the Progress of Thin-Film Transistors and Their Technologies for Flexible Electronics.” Micromachines, vol.12, no. 6, pp. 1 - 19, June 2021.

[6] A Shaban, J Telegdi, I Felhősi and M. Nikoletta, "Functional thin films and nanostructures for sensors," pp. 485-519, August 2018, DOI:10.1016/B978-0-323-51255-8.00016-1

[7] A. Romeo and E. Artegiani, CdTe-Based Thin Film Solar Cells: Past, Present and Future,” Energies 14, 1684, pp 1-24, March 2021.

[8] A. Hussain, A. Begum and A. Rahman "Characterization of Nanocrystalline Lead Sulphide Thin Films Prepared by Chemical Bath Deposition Technique," Arabian J. Sci. Eng. vol. 38, no. 1, Nov., 2013. DOI 10.1007/s13369-012-0390-3

[9] F. Gode, O. Baglayan and E. Guneri, "P-type nanostructure PbS thin films prepared by the SILAR method," Chalcogenide lett, vol. 12, no 10, pp. 519-528, Oct., 2015.

[10] S. Rajathi, K. Kirubavathi and K. Selvaraju, "Preparation of nanocrystalline Cd-doped PbS thin films and their structural and optical properties," J. Taibah University Sci. vol. 11, no. 6, pp. 1296-1305, June, 2017. https://doi.org/10.1016/j.jtusci.2017.05.001

[11] P. C. Okafor and A. J. Ekpunobi, "Effect of Manganese Doping Percentage on Band Gap Energy of Cadmium Sulphide (CdS) Nanofilms Prepared by Electrodeposition Method", Int. J. Sci. Res (IJSR), vol. 4, no. 12, pp. 2280-2284, Dec., 2015.

[12] R.S. S. Saravanan, M. Meena, D. Pukazhselvan and C.K.Mahadevan, "Structural, optical and electrical characterization of $\mathrm{Mn}^{2+}$ and $\mathrm{Cd}^{2+}$ doped/co-doped PbS nanocrystals" J. Alloys Comp. vol. 627, no. 5, pp. 69 - 77, April 2015.

[13] J. P. Mahashabde, A. M. Pati, K. C. Suryavanshi and S. N. Pate, "Structural properties of $\mathrm{Pb}_{1-\mathrm{x}} \mathrm{Mn}_{\mathrm{x}} \mathrm{S}$ thin films prepared by chemical bath deposition method," Int. J. Adv. Sci Techn. Res. vol. 3, no. 4, pp. 731-734, Mar. 2014. DOI:10.12693/APhysPolA.126.763.

[14] K. K. N. Chidambara, B. S. K. Khadeer and M. G. Shaki, "X-Ray line profile analysis of Mn doped PbS thin films by Successive Ionic Layer Adsorption and Reaction (SILAR) Method”. Int. J. Chem. Tech. Res. vol. 7, no. 5, pp. 2257-2264, 2015. http://www.sphinxsai.com > (2257-2264)V7N5

[15] K. K. N. Chidambara, S. K. Khadeer-Basha and M. G. Shakil, "Structural, optical and magnetic studies of Mn doped PbS thin films by SILAR method," Elixir Int. J Thin Film Technol.vol. 76, pp. 28336-28340, Nov., 2014.

[16] A. J. Yost, A. Pimachev, G. Rimal, J. Tang, Y. Dahnovsky and T. Chien, "Effects of Mn dopant locations on the electronic bandgap of PbS quantum dots," Appl. Phys. Lett. vol. 111, no. 23, pp. 1-5, December 2017. https://doi.org/10.1063/1.5004463

[17] S. Horoz, A. Ekinci and O. Sahin, "Synthesis of PbS and Ni-doped PbS thin films by CBD method and investigation of their structural, optical and photovoltaic properties," J. ovonic res. vol. 14, no. 3, pp. 201-208, June, 2018.

[18] M. A Hussain, L. R Singh and S. R. Devi, "Studies On Structural, Optical And Electrical Properties of Zn-Doped Pbs Nanocrystalline Thin Film," Chalcogenide Lett. Vol. 18, No. 3, pp. 103 - 111, March 2021.

[19] I. L. Ikhioya, S. Ehika and N. N. Omehe, "Electrochemical Deposition of Lead Sulphide (PbS) Thin Films Deposited on Zinc Plate Substrate," Journal of Materials Science Research and Reviews vol. 1, no. 3 pp. 1-11, October 2018.

[20] S. AlFaify, "Investigating Effects of Manganese Dopant on the Structure, Morphology and Optical Properties of the Nano Lead Sulfide Film," KKU J. Basic Appl. Sci. vol. 2, no. 2, pp. 18 -22, December 2016.

[21] M. Ahmed, M. Rabia and M. Shaban, The structure and photoelectrochemical activity of Cr-doped PbS thin films grown by chemical bath deposition," Royal Society of Chem. vol. 10, pp. 14458-14470, April 2020.

[22] Y. Gülen, "Characteristics of Ba-Doped PbS Thin Films Prepared by the SILAR Method" Acta Phy. Polonica A, vol. 126. no. 3, pp. 763 - 767, March 2014.

[23] G. Geetha, P. Murugasen and S. Sagadevan, "Synthesis and Characterization of Manganese Sulphide Thin Films by Chemical Bath Deposition Method," Acta Physica Polonica, vol. 132, no. 4, pp. 1221-1226, Sept., 2017. DOI: 10.12693/APhysPolA.132.1221

[24] A. N. Nwori, L. N. Ezenwaka E. I. Otti, N. A. Okereke, N. L. Okoli, "Optical, Electrical, Structural and morphological Properties of Electrodeposited CdMnS Thin Film Semiconductors for Possible Device Applications," J. Phys. Chem. Mater. vol. 8, no. 2, pp. 0111, June 2021.

[25] S. Rajathi, K. Kirubavathi K. Selvaraju "Structural, morphological, optical, and photoluminescence properties of nanocrystalline PbS thin films grown by chemical bath deposition," Arabian J. Chem. Vol. 10, no. 8, pp. 1167-1174, Dec., 2017. https://doi.org/10.1016/j.arabjc.2014.11.057

[26] O. Osanyinlusi, "Preparation and Characterization of ZnS Thin Films Grown by Spin Coating Technique," Tanzania J. Sci. vol 46, no 2, pp 534-547, June 2020.

[27] L. Beddek, M. Messaoudi, S. Guitouni, N. Attaf, M. S. Aida, "Structural, Optical and Electrical Properties of PbS Thin Films Deposited by CBD at Different Bath pH," Int. J. Sci. Res. Eng. Technol. (IJSET), vol.3, no. 2, pp. 138 - 142, 2015. 
Study of the Optical, Electrical, Structural and Morphological Properties of Electrodeposited Lead Manganese Sulphide ...........

[28] A. U. Ubale , K. S. Chipade , M.V. Bhute, P. P. Raut, G. P. Malpe, Y. S. Sakhare, M. R. Belkhedkar, "Structural, Optical and Electrical Properties of Nanostructured CdS:CuS Composite Thin Films Grown by CBD Method", Int. J. Mater. Chem. vol. 2, no. 4, pp. 165-172, 2012. doi: 10.5923/j.ijmc.20120204.09.

[29] M.P. Sarma and G. Wary, "Effect of Molarity on Structural and Optical Properties of Chemically Deposited Nanocrystalline PbS Thin Film,” Int. Lett. Chem. Phys. Astronomy, vol. 74, pp 22-35, June 2017.

[30] L. F. Koao, F. G. Hone and F. B. Dejene, "Synthesis and characterization of PbS nanowires doped with $\mathrm{Tb}^{3+}$ ions by using chemical bath deposition method," J. Nanostruct. Chem. Vol. 10, pp. 1-7, March 2020 https://doi.org/10.1007/s40097-019-00323-y

[31] M. Naftaly, S. Das, J. Gallop, K. Pan, F. Alkhalil, D. Kariyapperuma, S. Constant, C. Ramsdale and L. Hao, "Sheet Resistance Measurements of Conductive Thin Films: A Comparison of Techniques," Electronics, vol. 10, no. 960, pp. 1 - 10, April 2021. https://doi.org/10.3390/electronics10080960

[32] D. A. Oeba, "Optical and Electrical Properties of CdS: B Thin Film Deposited by Chemical Bath Deposition for Photovoltaic Application,” Int. J. Thin.Fil. Sci. Technol. vol. 8, no. 3, pp. 93-99, September 2019.

[33] N. Sanpo, J. Wang and C. C. Berndt, "Sol-gel synthesized copper-substituted cobalt ferrite nanoparticles for biomedical applications." J. nano res., vol. 25, pp. 110-121, Oct., 2013. https://doi.org/10.4028/www.scientific.net/JNanoR.25.110

[34] M. Karunakaran,, S. Maheswari, K. Kasirajan, S. D. Raj and R. Chandramohan, "Structural and Optical Properties of Mn-Doped ZnO Thin Films Prepared by SILAR Method," International Letters of Chemistry, Phys. Astro. vol. 73, no. 23, pp. 22-30, April, 2017. https://doi.org/10.18052/www.scipress.com/ILCPA.73.22.

[35] E. K. Nasr El Din, M. O. Dawood and A. M Ali, "Influence of Thickness on Structural and optical properties of the CdS single crystal nano structure thin films Deposited via Thermal evaporation”, Tikrit J. Pure Sci. vol. 24, no. 6, pp. 98-103, Nov. 2019. http://dx.doi.org/10.25130/j.v24i6.893.

[36] A. I. Hassan and S. I. Maki, "Structural and Optical Properties of Copper-Doped Cobalt Oxide Thin Films Prepared by Spray Pyrilysis," Int. J. Eng. \& Res. Technol. Vol. 6, no. 3, pp. 527-535, March. 2017, http://doi.org/10.5281/zenodo.439223.

[37] P. Prasoon, P. Jayaram, N. K. Sulfikkarali and N. K. Deepak, Micro-strain, "Dislocation Density, Surface Morphology and Optoelectronic Properties of Indium Zinc Oxide Thin Films," Int. J. Res. Advent Technol. 6, no. 12, pp. 3486-3491, December 2018.

[38] L. R. Singha and R. K. L. Singh, Effect of Dopant Concentration on Structural Properties of Chemical Bath Deposited Mn-Doped PbS Nanocrystalline Thin Films," Chalcogenide Letts, Vol. 17, No. 7, pp. 375 - 384, July 2020.

Publish your research article in AIJR journals-

- Online Submission and Tracking

- Peer-Reviewed

- Rapid decision

- Immediate Publication after acceptance

- Articles freely available online

- Retain full copyright of your article. Submit your article at journals.aijr.org
Publish your books with AIJR publisher-

- Publish with ISBN and DOI.

- Publish Thesis/Dissertation as Monograph.

- Publish Book Monograph.

- $\quad$ Publish Edited Volume/ Book.

- Publish Conference Proceedings

- Retain full copyright of your books.

Submit your manuscript at books.aijr.org 